\title{
PEMANFAATAN GULMA SEMAK BUNGA PUTIH (Chromolaena odorata) SEBAGAI BAHAN PEMBUAT PUPUK ORGANIK BOKHASI DALAM RANGKA MENGATASI PENYEMPITAN PADANG PEMGGEMBALAAN DAN MENCIPTAKAN PERTANIAN TERPADU BERBASIS ORGANIK
}

\author{
Johanis A. Jermias; Vinni D. Tome dan Tri A. Y. Foenay \\ ${ }^{1)}$ Politeknik Pertanian Negeri Kupang, \\ Email: jermiasjohanis@gmail.com; denivitatome@yahoo.co.id
}

\begin{abstract}
ABSTRAK
Dua masalah dalam bidang peternakan dan pertanian yang dihadapi oleh Kelompok Tani Moin Fe'u dan Kelompok Wanita Tani Moin Fe'u di Kelurahan Nonbes Kabupaten Kupang adalah: 1) invasi gulma semak bunga putih di padang penggembalaan yang mengancam ketersediaan pakan hijauan bagi ternak sapi; dan 2) ketergantungan terhadap pupuk anorganik untuk usaha pertanian tanaman hortikultura. Untuk membantu menyelesaikan kedua persoalan tersebut maka telah dilaksanakan kegiatan pengabdian pada masyarakat dengan memanfaatkan gulma tersebut sebagai bahan pembuat pupuk organik bokhasi bersama dengan feces sapi dan limbah pertanian lainnya. Kegiatan ini telah dilakukan dalam bentuk penyuluhan dan demonstrasi plot. Selanjutnya pupuk organik tersebut telah diaplikasikan pada tanaman hortikultura yang ditanam di pekarangan rumah dan lahan percontohan. Luaran yang diperoleh dari kegiatan ini adalah: i) penurunan gulma di padang penggembalaan sehingga meningkatkan ketersediaan pakan bagi ternak sapi milik mitra yang dipelihara secara ekxtensif; ii) terciptanya pemahaman mitra akan manfaat dari gulma semak bunga putih; iii) pemanfaatan feces sapi menjadi bahan dasar pembuatan pupuk organik; iv) penurunan tingkat ketergantungan mitra terhadap pupuk anorganik; v) keterampilan mitra dalam pembuatan pupuk organik; vi) produk berupa pupuk organik bokhasi; vii) lahan percontohan pertanian organic; dan viii) produk pertanian organik
\end{abstract}

Kata Kunci: bokhasi, organik, hortikultura, semak bunga putih 


\section{PENDAHULUAN}

Kecamatan Amarasi adalah salah satu Kecamatan di Kabupaten Kupang provinsi Nusa Tenggara Timur (NTT). Kecamatan ini memiliki 8 desa dan 1 Kelurahan. Masyarakat di Kecamatan ini umumnya adalah petani/peternak yang hidup dari bercocok tanam dan memelihara ternak. Jenis tanaman yang diusahakan adalah tanaman padi (sawah) dan tanaman hortikultura, sedangkan jenis ternak yang dipelihara adalah sapi, kuda, kerbau, kambing, babi, dan ayam (BPS Kabupaten Kupang, 2014).

Kecamatan Amarasi merupakan salah satu kantong produksi ternak sapi Kabupaten Kupang. Hal ini dibuktikan dengan posisi Kecamatan Amarasi pada urutan 2 dari data sebaran populasi ternak sapi di Kabupaten Kupang dengan jumlah populasi sebanyak 19.243 ekor atau sebesar $12.68 \%$ dari total sapi di Kabupaten Kupang (BPS Kabupaten Kupang, 2014). Sistem pemeliharaan ternak sapi yang diterapkan oleh masyarakat di Kecamatan ini terdiri dari 2 (dua) sistem yakni intensif dan ekstensif.

Pemeliharaan sapi secara intensif di wilayah ini dikenal dengan dengan budaya 'Paron", dimana dalam budaya ini pemilik sapi mengikat sapi-sapi jantan dewasa di bawah pohon atau dibuatkan kandang dengan tujuan untuk digemukkan dan dijual sebagai ternak potong ke luar NTT melalui pedagang antar pulau. Setelah sapi djual, maka peternak akan berusaha mencari sapi bakalan yang baru untuk digemukkan lagi. Dalam sistem ini, peternak hanya memanfaatkan hasil utamanya saja sedangkan hasil ikutan berupa feces tidak dimanfaatkan atau dibiarkan begitu saja, padahal sistem ini menghasilkan feces sebagai bahan baku pupuk organik yang sudah terkonsentrasi disekitar lokasi pemeliharaan.

Pemeliharaan ekstensif diterapkan pada ternak sapi induk dan anak, yakni ternak dilepaskan mencari makan di padang penggembalaan dan dikandangkan pada waktu malam. Sistem pemeliharaan ini merupakan sumber utama penghasil bibit dan bakalan bagi usaha peternakan sapi di Kecamatan Amarasi khususnya dan di wilayah Timor Barat pada umummya. 
Saat ini pemeliharaan induk dan anak sapi mengalami permasalahan yang cukup serius yakni menurunnya jumlah dan mutu padang penggembalaan yang disebabkan oleh beberapa faktor diantaranya alih fungsi padang penggembalaan menjadi areal pemukiman akibat pertambahan populasi penduduk dan invasi gulma semak bunga putih (Chromolaena odorata). Semak bunga putih adalah tanaman yang memiliki karakteristik pertumbuhan yang sangat cepat walaupun di lahan kritis. Tumbuhan ini menghasilkan biji yang banyak dan mudah tersebar dengan bantuan angin (Prawiradiputra, 2006). Selanjutnya menurut Prawiradiputra (2007), tanaman ini dianggap suatu gulma yang sangat merugikan karena: (1) dapat mengurangi kapasitas tampung padang penggembalaan, (2) dapat menyebabkan keracunan, bahkan mungkin sekali kematian ternak, (3) menimbulkan persaingan dengan rumput pakan, sehingga mengurangi produktivitas padang rumput, dan (4) dapat menimbulkan bahaya kebakaran terutama pada musim kemarau

Salah satu wilayah di Kecamatan Amarasi yang mengalami masalah akibat invasi gulma semak bunga putih adalah Kelurahan Nonbes. Penyebaran semak bunga putih di wilayah ini berjalan sangat cepat sehingga menyebabkan penurunan wilayah menggembala yang cukup signifikan. Usaha mengatasi tanaman ini sudah dilakukan dengan berbagai cara diantaranya menebas dan membakar namun tanaman ini kembali tumbuh lagi sehingga saat ini masyarakat cenderung pasrah menghadapi masalah tersebut. Keadaan ini tidak akan terjadi jika masyarakat mengetahui potensi yang dimiliki tanaman ini dan cara memanfaatkannya.

Pada sisi yang lain, usaha pertanian masyarakat di desa Nonbes (usaha pertanian sawah dan tanaman hortikultura) selalu mengandalkan pupuk kimia untuk mendapatkan hasil yang lebih baik. Kondisi ini menyebabkan mereka memiliki ketergantungan yang sangat tinggi terhadap pupuk kimia. Ketergantungan ini menyebabkan kebingungan bagi masyarakat ketika suplai dan distribusi pupuk tidak berjalan lancar seperti saat ini yang menyebabkan pengunduran musim tanam di sawah dan penurunan produksi tanaman hortikultura. Penggunaan pupuk kimia dalam waktu yang panjang dan berlebihan akan berdampak pada kondisi fisik tanah semakin buruk (Dwiyanto, dkk, 2001). 
Kelompok Tani Moin Fe'u di RT. 13 RW. 7 Kelurahan Nonbes adalah kelompok yang juga menghadapi persoalan invasi gulma semak bunga putih di padang penggembalaan dan ketergantungan yang tinggi terhadap pupuk kimia pada usaha pertanian. Untuk mengatasi persoalan tersebut maka telah dilaksanakan suatu kegiatan pengabdian masyarakat dalam bidang peternakan dan pertanian secara terpadu dengan memanfaatkan biomasa semak bunga putih, limbah usaha paronisasi sapi dan limbah pertanian untuk menghasilkan pupuk organic.

\section{MASALAH}

Berdasarkan kondisi di atas maka beberapa masalah yang telah diupayakan pemecahannya, yakni: 1). Ancaman penurunan ketersediaan jumlah pakan secara kontinyu di padang penggembalaan akibat pesatnya perkembangan tanaman gulma semak bunga putih 2). Terbatasnya pemahaman mitra akan manfaat yang bisa didapatkan dari gulma semak bunga putih 3). Belum optimalnya pemanfaatan limbah (feces) dari usaha peternakan sapi intensif (paron) yang memiliki potensi besar bagi usaha pertanian 4) Ketergantungan mitra yang tinggi akan pupuk anorganik sehingga ketika suplai dan distribusi pupuk anorganik terhambat akan berpengaruh terhadap waktu tanam dan hasil panen tanaman hortikultura 5). Terbatasnya pemahaman dan pengalaman mitra dalam membuat dan menggunakan pupuk organik dalam usaha pertanian mereka.

\section{METODE PELAKSANAAN}

Guna membantu menyelesaikan permasalahan yang dihadapi oleh mitra selama ini, maka bentuk kegiatan yang telah dilakukan adalah melakukan penyuluhan dan demonstrasi yang berkaitan dengan masalah mitra tersebut.

Kegiatan penyuluhan dilaksanakan dalam bentuk ceramah dan diskusi mengenai: 1). Mengenal tanaman gulma semak bunga putih dan potensi yang dimiliki; 2). Pembuatan pupuk organic (bokhasi) dengan menggunakan tanaman gulma semak bunga putih, limbah paronisasi sapi (feces), dan limbah pertanian; 3). Aplikasi pupuk bokhasi pada tanaman hortikultura 
Selanjutnya guna memperjelas pemahaman mitra maka telah dilakukan demonstrasi plot pembuatan bokhasi dan aplikasinya pada usaha pertanian tanaman hortikulutra dengan menggunakan pupuk bokhasi yang dibuat sendiri oleh mitra. Aplikasi ini dilakukan pada tanaman yang ditanam di pekarangan rumah dan di lokasi lahan percontohan kelompok.

Aplikasi ini juga sekaligus merupakan suatu kegiatan pengamatan bersama antara tim pelaksana kegiatan pengabdian dan kelompok sasaran untuk membuktikan kemanjuran dari pupuk bokhasi dibandingkan dengan pupuk anorganik sehingga diharapkan dengan melihat langsung hasil panen tanaman hortikultura yang menggunakan pupuk bokhasi maka akan menghasilkan tingkat adopsi mitra yang tinggi terhadap teknologi bokhasi.

Produk dari kegiatan ini berupa pupuk bokhasi berbahan dasar gulma semak bunga putih, limbah peternakan, dan pertanian dan produk berupa hasil pertanian hortikultura organic yang sebagian telah berhasil dijual oleh mitra ke pasar..

Adapun pola kegiatan dalam solusi yang ditawarkan di atas adalah sebagai berikut:

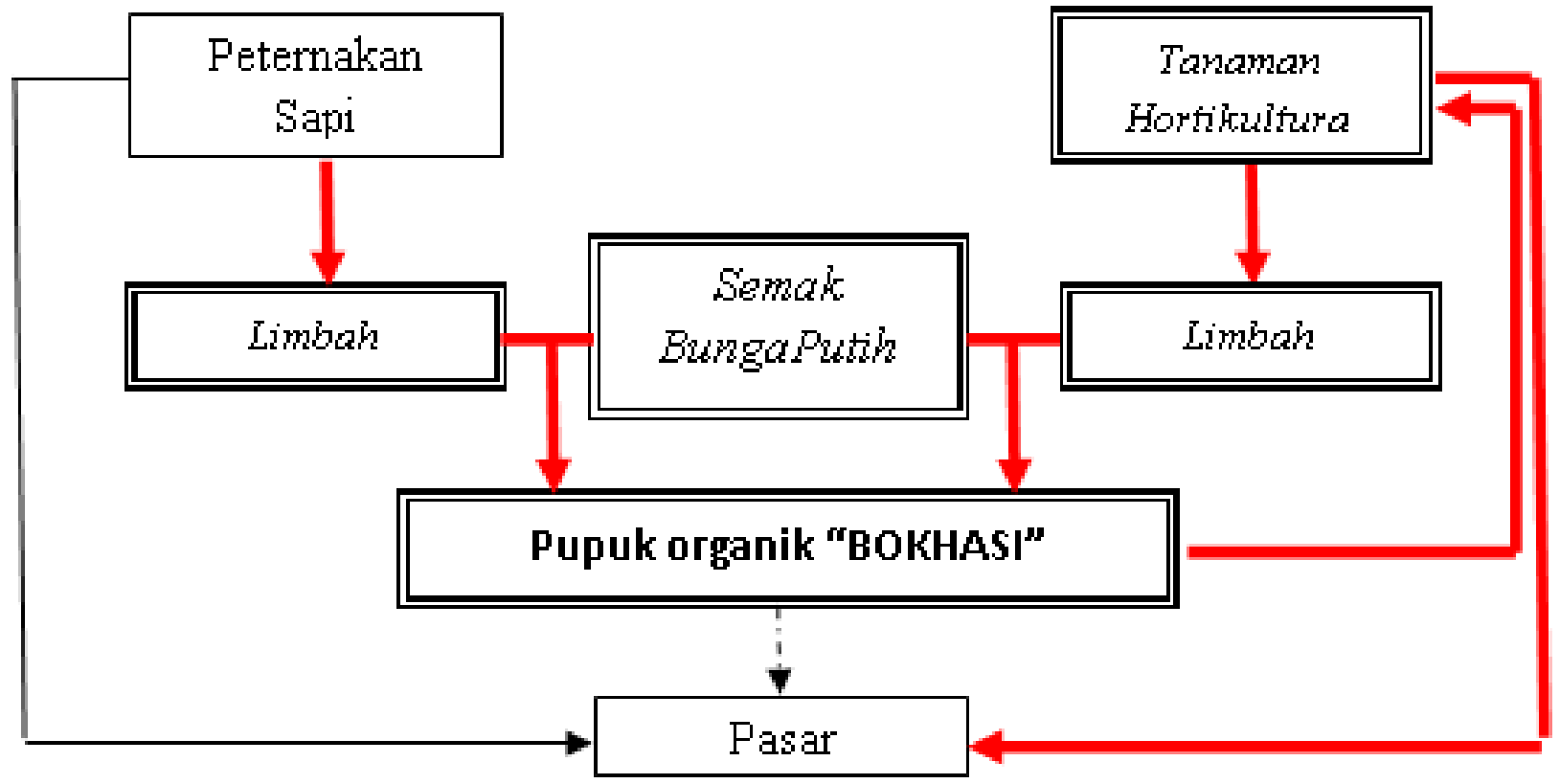

Kegiatan yang telah dilaksanakan bersifat stimulant dengan harapan dapat meningkatkan kesadaran, pengetahuan dan keterampilan mitra. Dalam kegiatan ini mitra dilibatkan secara aktif 
mengikuti kegiatan mulai dari ceramah, diskusi, penyiapan bahan-bahan pembuat bokhasi semak bunga putih (feces sapi, tanaman semak bunga putih, dan limbah lainnya), persiapan lahan untuk uji coba pupuk bokhasi semak bunga putih, aplikasi pupuk bokhasi semak bunga putih pada tanaman hortikultura (tomat, cabai, terung dan sayur-sayuran), pengamatan pertumbuhan dan hasil tanaman hortikulutra yang menggunakan pupuk bokhasi semak bunga putih serta membandingkannya dengan tanaman hortikultura yang dihasilkan dengan menggunakan pupuk anorganik.

Hasil yang diperoleh dari kegiatan ini adalah produk berupa sistem peternakan dan pertanian tanaman pangan dan hortikultura yang terintegrasi dan berbasis organik. Diharapkan hasil kegiatan ini dapat menjadi suatu motivator bagi kelompok tani dalam mengatasi gulma di padang penggembalaan, memanfaatkan limbah peternakan dan pertanian, dan mengatasi ketergantungan terhadap pupuk anorganik. Keuntungan lanjutan yang diharapkan diperoleh dari kegiatan ini adalah dapat memperbaiki kondisi tanah akibat penggunaan pupuk anorganik pada waktu yang lalu.

Selanjutnya pengetahuan yang telah dimiliki mitra tersebut diharapkan dapat disebarluaskan kepada masyarakat lain sehingga usaha pertanian dan peternakan di desa Nonbes akan berkembang menjadi lebih baik.

\section{HASIL YANG DICAPAI}

Dari kegiatan pengabdian ini telah dihasilkan suatu integrasi usaha peternakan-pertanian yang berbasis organik dengan memanfaatkan gulma semak bunga putih dan limbah peternakanpertanian.

Secara spesifik, luaran dari kegiatan pengabdian masyarakat di Kelompok Tani Moin Fe'u yang menghadapi masalah invasi gulma semak bunga putih di padang penggembalaan dan ketergantungan terhadap pupuk anorganik dalam usaha pertanian adalah sebagai berikut: 
1. penurunan gulma semak bunga putih di padang penggembalaan sehingga meningkatkan ketersediaan pakan bagi ternak sapi milik mitra yang dipelihara secara ekxtensif

2. terciptanya pemahaman mitra akan manfaat dari gulma semak bunga putih

3. pemanfaatan feces sapi menjadi bahan dasar pembuatan pupuk organic

4. penurunan tingkat ketergantungan mitra terhadap pupuk anorganik

5. keterampilan mitra dalam pembuatan pupuk organik bokhasi

6. produk berupa pupuk organik bokhasi

7. lahan percontohan pertanian organik

8. produk pertanian organic

\section{KESIMPULAN}

Hasil evaluasi terhadap proses pelaksanaan kegiatan pengabdian masyarajat ini menunjukkan adanya penurunan jumlah titik semak bunga putih di padang Penggembalaan. Selain itu kegiatan ini telah mampu membuat kelompok tidak menggunakan pupuk anorganik selama musim tanam tahun 2015. Kegiatan ini telah mendapatkan sambutan yang antuasis dari anggota kelompok sasaran dalam bentuk partisipasi yang sangat aktif dalam berbagai kegiatan yang dilakukan. Hal ini juga dibuktikan dengan adanya upaya pembukaan lahan pertanian baru untuk dijadikan lahan pertanian organik dengan menggunakan pupuk organik bokhasi.

Karena itu maka disarankan agar perlu dilakukan kegiatan lanjutan dalam kelompok ini untuk menunjang dan mensukseskan rencana mewujudkan pertanian hortikultura berbasis organik dengan memanfaatkan potensi lokal yang ada. Berbagai kegiatan lanjutan yang dibutuhkan antara lain: manajemen organisasi kelompok tani, manajemen keuangan, penanganan hama dan penyakit tanaman secara organic, strategi memanfaatkan air yang jumlahnya terbatas, dan pertanian terpadu yang menggabungkan usaha pertanian tanaman pangan, peternakan, perikanan, dan kehutanan dengan konsep zero waste. 


\section{DAFTAR PUSTAKA}

Badan Pusat Statistik Kabupaten Kupang, (2014). Kabupaten Kupang dalam Angka 2013.

Dwiyanto, K., Prawiradiputra, B.R., Lubis, D. (2001). Integrasi Tanaman-Ternak dalam pengembangan Agribisnis yang Berdaya Saing, Berkelanjutan, dan Berkerakyatan. Seminar Nasional Teknologi Peternakan dan Veteriner.

Prawiradiputra, B.R. (2007). Ki Rinyuh (Chromolaena odorata (L) R.M. King dan H. Robinson): Gulma Padang Rumput yang Merugikan. Buletin Ilmu Peternakan Indonesia (WARTAZOA), Volume 17 No. 1.

Prawiradiputra, B.R. (2006). Hijauan Pakan Ternak di Indonesia. Badan Litbang Pertanian pada tahun 2006. 